\title{
Tax Compliance for Sustainable Development by Private Health Practitioners in Malaysia
}

\author{
Norlaila Md Zin ${ }^{1}$, Noratikah Arifin², Eley Suzana Kasim ${ }^{3 *}$, \\ Mohd Haizam Mohd Saudi ${ }^{4}$ and Isyahira Ismail ${ }^{5}$ \\ ${ }^{1}$ Faculty of Accountancy, UiTM, Kampus Seremban \\ ${ }^{2}$ Faculty of Accountancy, UiTM Cawangan Selangor Kampus Puncak Alam \\ ${ }^{3}$ Accounting Research Institute (HICoE) \& Faculty of Accountancy, \\ UiTM Kampus Seremban Seremban \\ ${ }^{4}$ Widyatama University Ringgold Standard Institution, Indonesia \\ ${ }^{5}$ Bakertilly Monteiro Heng, Malaysia
}

\begin{abstract}
Tax non-compliance leads to tax evasion and low tax collection, which ultimately may hamper the achievement of Sustainable Development Goals (SDGs). Prior studies suggest that tax compliance is influenced by taxpayers' attitude, quality of public governance and cost of tax compliance. However, studies that focus on tax compliance among health practitioners are still sparse. Given that potential tax evasion among private health practitioners may lead to a significant loss in government revenue, this study aimed to examine the factors influencing tax compliance among private health practitioners. Data was gathered through a survey involving 271 health practitioners in Malaysia. The findings indicated that only the quality of public governance had a significant relationship with tax compliance while attitude of taxpayers and cost of tax compliance did not significantly influence tax compliance among private health practitioners. This study contributes to the body of knowledge by providing current evidence of tax compliance among health practitioners. By highlighting the importance of educating health practitioners on tax compliance, the study also provides guidance to regulators in planning for more effective tax education and awareness programs.
\end{abstract}

Keywords: tax compliance, attitude of taxpayer, quality of public governance, tax compliance cost, health practitioners

ARTICLE INFO

Article History:

Received: 10 March 2021

Accepted: 25 August 2021

Published: 1 December 2021

* Corresponding author: Eley Suzana Kasim. Email: ekasim@uitm.edu.my 


\section{INTRODUCTION}

Tax revenue is one of the resources for government expenditure for a nation's development (Fan, Pang, \& Pestieau, 2020; Tsaurai, 2020). To achieve Sustainable Development Goals (SDGs), it is necessary that tax systems are efficient (OECD, 2018). The share of tax in total revenues and the amount of tax collected differs among countries and this depends on the structure of the economy in each country (Reshetov, Mysachenko, \& Mikhailova, 2020). In Malaysia, government income exceedingly relies upon individual taxpayers. In 2017, the total income tax revenue from individual taxpayers was RM30.1 billion, i.e., $47.2 \%$ from the total tax revenue (Inland Revenue Board Malaysia, 2017). This indicates that individual taxpayers contribute significantly to the government. Therefore, the Inland Revenue Board Malaysia (IRBM) needs to promote individual compliance by increasing compliance-related activities such as roadshows and campaigns.

Low tax compliance occurs due to many reasons. For example, people just try to avoid declaring their wealth, as they do not want to pay tax or they prefer to save that money for their own use (Jayawardane \& Low, 2017). In the presence of low tax compliance, the government cannot allocate revenue for programs which provide desirable social services. Thus, understanding why low tax compliance happens and knowing factors that cause tax compliance is very important to increase tax compliance.

Tax compliance refers to the level in which a taxpayer complies with or neglects the tax laws in a country which can be exercised by pronouncing income, paying the tax due in a timely manner and filing a tax return form (Gobena \& Van, 2016). As indicated by Fochmann and Kroll (2016), tax compliance is how much a taxpayer is obligated to tax governance and controls. This includes the idea of tax compliance on "the willingness of an individual and other taxable entity to act in accordance and within the spirit as well as the letter of tax law and administration without the application of enforcement activity".

Despite many studies on tax compliance conducted in developed countries, there are however a lack of studies on tax compliance in Malaysia, specifically regarding tax compliance among private health practitioners. Some related studies, such as Kasipillai et al. (2000), Jaffar Harun et al. 
(2011) and Fatt and Ling (2008) have investigated the relationship between education, tax audit and tax evasion. The studies also discussed ethics on tax compliance in Malaysia. However, none have looked specifically at the factors affecting tax compliance among health practitioners.

Mehari and Pasha (2017) noted that tax compliance has been an important issue to study in many countries. Each country has its own strategy in managing tax compliance levels through different tax laws and regulations, thus the factors influencing tax compliance may be different between countries. IRBM (2016) estimated about RM1 billion loss to the government as there was low tax collection from professionals including doctors (IRBM, 2016). Additionally, Free Malaysia Today (2017) reported the collection of individual income tax from health practitioners in 2016 and 2017 had become an issue because the tax collection was low. Realising the significant effect of tax compliance on an economy and a lack of studies in this area for Malaysia particularly among health practitioners, this study attempted to examine the factors influencing tax compliance among health practitioners. More specifically, this study aimed to achieve the following sub-objectives:

1. To examine the relationship between attitude of taxpayers and tax compliance among private health practitioners.

2. To examine the relationship between quality of public governance and tax compliance among private health practitioners.

3. To examine the relationship between cost of tax compliance and tax compliance among private health practitioners.

\section{LITERATURE REVIEW}

\section{Tax Compliance and Sustainable Development Goals}

The achievement of the SDGs requires substantial development finance which include a nation's source of income in the form of tax revenue (Long \& Miller, 2017). In addition, Hearson (2019) asserted that to bridge the SDG financing gap, developing countries need to increase tax compliance. Mehari and Pasha (2017) asserted that tax compliance relates to taxpayers' readiness to obey tax laws with a specific end goal to 
obtain economic balance of a nation. A more straightforward definition of tax compliance involves taxpayers' willingness to comply with tax laws which are determined by ethics, the legal environment and other situational factors at a particular time and place (Bulutoding, 2018). Additionally, tax compliance is likewise characterized by a few tax experts as the capacity and willingness of taxpayers to agree to the tax laws to proclaim the right income every year and pay the correct amount of taxes on time (IRBM, 2016). Meanwhile, Jayawardane and Low (2017) and Ketema (2016) characterized tax compliance as the detailing of all income and payment of all duties by fulfilling the provisions of laws, regulations and court judgments. Saad (2014) and Saad et al. (2016) suggested that tax compliance can be classified into two points of view: compliance regarding administration and compliance in terms of completing (accurately) the tax returns. A more extensive viewpoint of tax compliance is likewise delineated in the definition given by Fochmann et al. (2016) which is the coveted result because of compliance to respect laws to obtain an economic equilibrium.

\section{Tax Compliance among Health Practitioners}

Individual taxpayers who are health practitioners were the subject of this study and it is particularly important to examine factors influencing tax compliance. Health practitioners, like other business owners in Malaysia, are subject to income tax. The taxation of both individuals and corporations is mainly governed by the Income Tax Act 1967. According to the income tax laws relating to businesses in Malaysia, tax compliance requirements are keeping up to date books of accounts, determining the taxable income according to the stipulated rules and regulations, accurate determination of tax liability, filing of returns on income by the prescribed date (IRBM, 2017). Although Stefura (2011) found that health practitioners have the highest intention for tax compliance compared to accountants and lawyers, Dwita et al. (2019) suggested that health practitioners still lack tax knowledge which could affect tax compliance.

Tax non-compliance might be in one of numerous structures; it could either be the inability to submit a tax return within the stipulated period or no submission, understatement of income, overstatement of deductions, or failure to pay assessed taxes by due date (Chyz et al., 2014). In some cases, non-compliance may mean an outright failure to pay levied taxes. 
Studies have demonstrated that the issue of tax evasion is a far reaching one. Moreover, Mafrolla, and D'Amico (2016) found that it is predominant in creating nations and it upsets improvement in this manner prompting financial stagnation and other financial issues. Mas'ud et al. (2014) and Palil (2010) recognized tax rates and complex filling methods as the reasons for tax non-compliance. They argued that a higher tax rate increases taxpayers' burden and reduces their excess money in this way, increasing the likelihood of tax evasion.

\section{Conceptual Framework and Hypotheses Development}

Figure 1 shows the conceptual framework of this study. The framework identifies three independent variables consisting of: (1) attitude of taxpayers, (2) quality of public governance and (3) cost of tax compliance. The dependent variable in this framework is tax compliance.

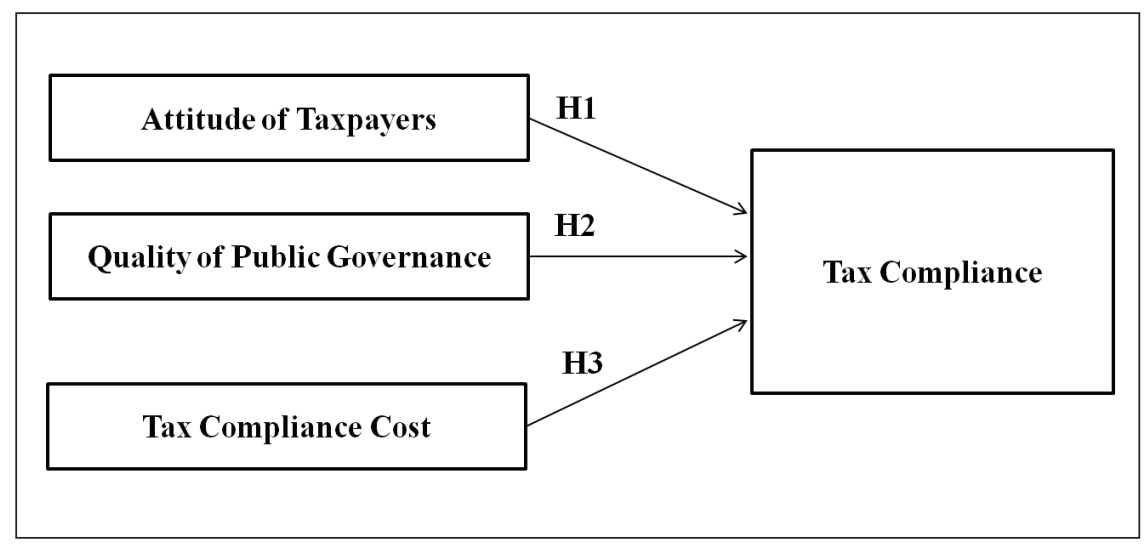

Figure 1: Conceptual Framework of the Research

\section{Attitude of Taxpayers and Tax Compliance}

An attitude indicates an individual's settled way of thinking or feeling about something that may influence decision making. Tax compliance is one such aspect that is subject to attitudes that taxpayers hold. For example, taxpayers are unlikely to comply voluntarily if they feel that the tax system is unfair. Besides, if taxpayers feel that the taxes are not used properly, then they will refuse to pay tax. As indicated by Bulotoding (2018), an individual's interest and preference regarding tax compliance referrs to 
attitude of taxpayers. Attitude is also considered as having a positive or a negative mind (Ketema, 2016). In other words, taxpayers with a positive attitude will comply with tax laws whereas those with a negative attitude will not comply with the said law. Moreover, Machogu (2015) found that low income nations have the lowest level of compliance. For instance, financial deficit may cause taxpayers not to pay tax. Therefore, this study aims to see whether health practitioners are influenced by their attitude in complying with the tax laws. The hypothesis was developed as follows:

$\mathbf{H}_{\mathbf{1}}$ : There is a significant relationship between attitude of taxpayers and tax compliance among private health practitioners.

\section{Quality of Public Governance and Tax Compliance}

One of the influential factors in tax compliance is the quality of public governance provided to citizens. In general, basic services such as enhancing security and building infrastructure are some of the expectations of citizens when they pay taxes. Therefore, taxpayers may refuse to pay tax if they deem that the services they receive are inadequate. This means that taxpayers will pay tax when they are satisfied with the infrastructure. Decisions made by the government should matter to taxpayers since they are the ones who pay the tax. Mohdali et al. (2014) found that taxpayers seeing that the government is competent may contribute to high tax compliance, whereas feeling that the government is not competent, may contribute to low tax compliance. Additionally, taxpayers may avoid or evade paying tax if they find that the government has not provided good service and infrastructure (Machogu, 2015). Therefore, this scenario shows that the quality of public governance and tax compliance are related. Due to the limited literature on the relationship between the quality of public governance and tax compliance, this study suggests that the quality of public governance could impact tax compliance and hence, the hypothesis was developed as follows:

$\mathbf{H}_{2}$ : There is a significant relationship between quality of public governance and tax compliance among private health practitioners. 


\section{Tax Compliance Cost and Tax Compliance}

Costs of tax compliance refers to additional costs that are incurred in the future when a taxpayer does not comply to pay tax. Tax compliance costs include costs such as penalties, fines and imprisonment (Ketema, 2016). Additionally, taxpayers may comply when the non-compliance costs are high and vice versa. The consequences of future tax costs must be borne by taxpayers should non-compliance activities be detected by tax authorities. A study conducted by Kogler, Mittone, and Kirchler, (2016), revealed that the level of compliance will be higher as a result of an increase in fines, compared to tax audits. Therefore, this scenario shows that the cost of non-compliance and tax compliance are related. According to Machogu (2015), due to the lack of literature on the relationship between the cost of non-compliance and tax compliance, this study suggests that the cost of non-compliance could impact tax compliance and hence, the hypothesis was developed as follows:

$\mathbf{H}_{3}$ : There is a significant relationship between tax compliance cost and tax compliance among private health practitioners

\section{METHODOLOGY}

Based on the objective of this study which was to examine factors influencing tax compliance among health practitioners, the quantitative methodology was deemed the most appropriate to collect measurable and numerical data. The primary data was collected using a survey to gather general information of the respondents, and the relationship between attitude of taxpayers, quality of public governance, tax compliance cost and tax compliance. To achieve the research objectives, this study relied on a questionnaire survey as the research instrument to collect the data. In this study, 161 questionnaires were submitted by hand whereas 110 questionnaires were submitted through email.

\section{Unit of Analysis}

A unit of analysis can be defined as the subject that the analyst may generalise (Beck et al., 2004). It is the most basic element and the major entity in research. The unit of analysis in this study was health practitioners 
who owned clinics. The health practitioners were chosen as the unit analysis because there was low tax collection from them for two consecutive years, in 2016 and 2017.

\section{Sample Selection}

The population of this study are the clinics in Negeri Sembilan and Selangor. Most of the clinics are registered under the Ministry of Health. In 2017, based on data from the Ministry of Health directory, there were 27\% clinics located in Selangor, followed by Kuala Lumpur (14\%), Johor (12\%), Perak (9\%), Pulau Pinang (7\%), Kedah (5\%), Sabah (5\%), Sarawak (5\%), Melaka (4\%), Negeri Sembilan (4\%), Kelantan (3\%), Pahang (3\%) and Terengganu (2\%). This study used the cluster random sampling technique through which each private clinic would have an equal chance of being selected within each cluster.

\section{Questionnaire Design}

The questionnaire consisted of four sections: Part A: General information on the respondents, Part B: Attitude of Taxpayers, Part C: Quality of Public Governance and Part D: Tax Compliance Cost. The survey questionnaire was adopted from Machogu (2015) and Ketema (2016). Part A identified the general information of the respondents such as gender, race, age, marital status, religion, highest level of education, tax filing, gross monthly income, and preparation of tax returns. Meanwhile Part B examined the attitude of taxpayers and tax compliance. Part $\mathrm{C}$ examined the quality of public governance and tax compliance. The questions were related to tax laws, tax obligation, tax system and government service. The questions were to show whether the quality of public governance impacted tax compliance. Part D finally addressed the relationship between cost of tax compliance and tax compliance.

\section{Measurement of Variables}

The first part of the survey, Part A, measured tax compliance. Tax compliance was measured based on a nominal scale which is about complying or not complying of tax returns. It was adapted from Ketema (2016). Subseqeuntly, Part B of the survey measured the influence of taxpayers' attitude towards tax compliance. Taxpayers' attitude towards 
taxation can be either positive or negative. This means that, a negative state of mind builds up non-compliance whereas a positive attitude encourages compliance. For this variable, this study used a 5-point Likert scale ranging from one (Strongly Agree) to five (Strongly Disagree). The measurement in Part B was adopted from Machogu (2015). Part C of the survey measured the influence of the quality of public governance on tax compliance. The perception on the quality of public governance can be either positive or negative. Lastly, in part $\mathrm{D}$, the survey covered the influence of cost of tax compliance on tax compliance. For the tax compliance cost variable, this study used a 5-point Likert scale ranging from one (Strongly Agree) to five (Strongly Disagree).

\section{Data Collection}

Two hundred and seventy-one (271) questionnaires were sent to all private clinics in Selangor and Negeri Sembilan. Out of the 271 questionnaires, 110 were sent through email while 161 questionnaires were distributed by hand as shown in Table 1 .

Table 1: Summary of Questionnaires Distribution

\begin{tabular}{lccc}
\multicolumn{1}{c}{ State } & Hand & Email & Total \\
\hline Negeri Sembilan & 102 & 55 & 146 \\
Selangor & 59 & 55 & 114 \\
Total & 161 & 110 & 271 \\
\hline
\end{tabular}

Out of 161 questionnaires distributed by hand, 102 questionnaires were sent to private clinics located in Negeri Sembilan and 59 questionnaires were sent to private clinics in Selangor. The distribution of questionnaires was conducted in three phases. During the first phase, 100 questionnaires were distributed by hand. The respondents were given two (2) weeks to complete the questionnaires. After a week, telephone calls were made to remind the respondents to complete the questionnaires. However, only 48 questionnaires were returned and completed. The remaining questionnaires were incomplete due to the respondents' refusal to participate.

In order to have more respondents, 110 questionnaires were distributed through e-mails during the second phase. All of the email addresses were obtained from the internet. However, only 15 responses were obtained (nine from Selangor and six from Negeri Sembilan). The reasons given for 
non-responses were health practitioners' unavailability due to workload, no knowledge, refusal to participate and the clinics' ceasing to operate. Due to the insufficient number of responses, an additional 50 questionnaires were distributed by hand during the third phase. Distribution by hand allowed for fast responses hence it was more efficient. However, due to the General Election at that time, it placed time constraints on the health practitioners in completing the survey. Follow up calls were made six days later to remind and alert the respondents of the questionnaires. From the third batch of questionnaires, only 32 respondents completed the questionnaires.

Finally, the total number of respondents for this study was 95 comprising 62 respondents from Negeri Sembilan and 33 from Selangor representing a 35.06 percent response rate. The usable sample size of this study is considered acceptable according to Sekaran (2010), where a sample size which is larger than 30 and less than 500 is appropriate for most researchers. The data collected from the questionnaires were analysed using the Statistical Package for Social Science (SPSS). The analysis done was descriptive analysis, normality test and regression analysis.

\section{FINDINGS}

\section{Demographic Information}

Findings on the demographic profile of respondents are presented in Table 2. From a total of 95 respondents, 56 of them were male and 39 were female. A majority of the respondents were between 41 years of age to 60 years of age with a percentage of $57.9 \%$ (55 respondents). This indicated that most of the clinic owners had medical experience before they launched their clinics. The distribution showed that most of the respondents who owned a clinic had higher education and perhaps had a high understanding about tax compliance. Eight respondents (8.4\%) held a degree qualification. 
Table 2: Demographic Information of the Respondents

\begin{tabular}{llcc}
\hline Demographic variables & \multicolumn{1}{c}{ Categories } & Frequency & $\begin{array}{c}\text { Percentage } \\
(\%)\end{array}$ \\
\hline Gender of Respondent & Male & 56 & 58.9 \\
& Female & 39 & 41.1 \\
& Malay & 37 & 38.9 \\
& Chinese & 22 & 23.2 \\
Age & Indian & 36 & 37.9 \\
& $(20-40)$ & 34 & 35.8 \\
Marital status & $(41-60)$ & 55 & 57.9 \\
Religion & $(61-80)$ & 6 & 6.3 \\
& Married & 67 & 70.5 \\
\multirow{5}{*}{ Highest Education } & Not married & 28 & 29.5 \\
\multirow{4}{*}{ Used of E-filing } & Islam & 42 & 44.2 \\
\multirow{4}{*}{ Monthly income } & Buddha & 19 & 20.0 \\
& Hindu & 34 & 35.8 \\
& MBSS & 87 & 91.6 \\
& Degree & 8 & 8.4 \\
& Yes & 27 & 28.4 \\
& No & 68 & 71.6 \\
& RM1,000-RM5,000 & 39 & 41.1 \\
& RM5,001-RM10,000 & 52 & 54.7 \\
& RM10,001-RM15,000 & 4 & 4.2 \\
\hline
\end{tabular}

The respondents were also asked about the use of e-filing. $71.6 \%$ did not use e-filing because they had assistance and paid agents to fill up the e-filing. They believed that agents have more knowledge compared to them. However, $28.4 \%$ respondents had used e-filing in order to comply with the tax system. This showed that some health practitioners had knowledge on using e-filing.

\section{Tax Compliance}

Descriptive statistics of tax compliance is shown in Table 3. Tax compliance was measured by the compliance of tax returns. Respondents were asked if they had been filing a tax return. According to the results, the frequency of tax compliance by health practitioners was 52 while frequency of non-compliance was 43 . Thus, the results showed that most of the respondents complied with percentage of $54.7 \%$. 
Table 3: Descriptive Statistics of Tax Compliance

\begin{tabular}{ccc}
\hline Tax Compliance & Yes / Not Comply & No / Comply \\
\hline Not filing a tax return & 43 & 52 \\
\hline
\end{tabular}

\section{Attitude of Taxpayer}

Based on the results, the average mean score for attitude of taxpayer was 2.25 while the standard deviation was 1.111 (Table 4). It means that most of the respondents agreed to the statement. Hence, it showed that health practitioners had a positive attitude towards tax compliance. However, a standard deviation of 1.111 indicated the presence of a considerable discrepancy in the way people perceived their obligations to remit their taxes as required by law.

Table 4: Descriptive Statistics of Attitude of Taxpayer

\begin{tabular}{|c|c|c|}
\hline Attitude of Taxpayers & Mean & Std. Deviation \\
\hline Omitting or understating my taxable income is wrong. & 2.17 & 0.996 \\
\hline $\begin{array}{l}\text { It is wrong to understate income since it does really } \\
\text { hurt anyone. }\end{array}$ & 2.04 & 1.091 \\
\hline $\begin{array}{l}\text { It is wrong to declare less taxable income because } \\
\text { the government uses taxpayers' money extravagantly. }\end{array}$ & 2.54 & 1.359 \\
\hline $\begin{array}{l}\text { Since several taxpayers do not pay income taxes at all, } \\
\text { there is big issue if I understate my income. }\end{array}$ & 2.24 & 0.997 \\
\hline Average mean and standard deviation & 2.25 & 1.111 \\
\hline
\end{tabular}

\section{Quality of Public Governance}

As indicated in Table 5, the overall mean of 3.06 showed that the health practitioners moderately agreed with the view that quality of public governance is important for tax compliance. However, a standard deviation of 0.911 indicated a considerable dispersion in the way people perceive their obligations to remit their taxes as required by law. Rounding off the mean to the nearest one, the value was 3 . Based on the rating scale use, 3 meant that most of the health practitioners agreed with this statement. This showed that health practitioners had a good expectation on the quality of public governance in influencing tax compliance. 
Table 5: Descriptive Statistics of Quality of Public Governance

\begin{tabular}{lcc}
\hline \multicolumn{1}{c}{ Quality of Public Governance } & Mean & Std. Deviation \\
\hline $\begin{array}{l}\text { I easily understand tax laws for example on rates of tax, } \\
\text { filing and payment dates. }\end{array}$ & 2.64 & 0.922 \\
$\begin{array}{l}\text { I feel thatthetaxsystem isjusthence I paymyfairshare of tax. } \\
\text { I believe that my neighbours are reporting and paying }\end{array}$ & 2.96 & 0.930 \\
$\begin{array}{l}\text { Iaxes honestly. } \\
\text { I pay taxes because I feel that tax is an obligation. }\end{array}$ & 2.99 & 0.986 \\
$\begin{array}{l}\text { I remit my taxes because the government portrays a } \\
\text { positive image i.e., government is fighting corruption } \\
\text { and is achieving tax objectives. }\end{array}$ & 3.61 & 0.914 \\
\begin{tabular}{l} 
Average mean and standard deviation \\
\hline
\end{tabular} & 3.06 & 0.911 \\
\hline
\end{tabular}

\section{Tax Compliance Cost}

As mentioned previously, the items on tax compliance cost variable used a 5-point Likert scale ranging from one (Strongly Agree) to five (Strongly Disagree). The results on tax compliance cost showed a mean of 3.99 with a standard deviation of 0.701 (Table 6). Rounding off to the nearest one, the value was 4 . Based on the rating scale used, 4 meant that the health practitioners viewed that cost of tax compliance did not influence the health practitioners to comply with tax requirements.

Table 6: Descriptive Statistics of Tax Compliance Cost

\begin{tabular}{lcc}
\hline \multicolumn{1}{c}{ Tax Compliance Cost } & Mean & Std. Deviation \\
\hline $\begin{array}{l}\text { The possibility of being audited is so low such that it is } \\
\text { sensible to make a slight understatement on my taxable }\end{array}$ & & 0.668 \\
income. & & \\
$\begin{array}{l}\text { Income taxes rates are too high such that it is not really } \\
\text { cheating when I look for ways to pay less than I am }\end{array}$ & & 0.718 \\
$\begin{array}{l}\text { supposed to. } \\
\text { I remit my taxes to avoid paying fines and penalties. }\end{array}$ & 4.15 & 0.668 \\
$\begin{array}{l}\text { I pay taxes because there is a high possibility of being } \\
\text { detected for non-compliance. }\end{array}$ & 3.59 & 0.751 \\
Average mean and standard deviation & 3.99 & 0.701 \\
\hline
\end{tabular}

\section{Normality Test}

The analysis in determining differences in mean scores of attitude of health practitioners, quality of public governance and tax compliance cost 
between tax compliance involves the use of test of significant difference. The appropriate statistical tools for this depend on whether the observation values (total scores) are normally distributed or otherwise. A normality test was carried out using the One-Sample Kolmogorov-Smirnov Test on the total scores accumulated number of cases and period of the outbreak, and the summary statistics of which are presented in Table 7.

Table 7: Summary Statistics of One-Sample Kolmogorov-Smirnov Test (K-S) on Total Scores

\begin{tabular}{lcc}
\hline Dimension & $\begin{array}{c}\text { Kolmogorov-Smirnov (K-S) Test Statistic } \\
\text { K-S Z-value }\end{array}$ & $\begin{array}{c}\text { p-value } \\
\text { Attitude of taxpayers }\end{array}$ \\
Quality of public governance & 0.795 & 0.517 \\
Tax Compliance Cost & 0.647 & 0.529 \\
\hline
\end{tabular}

It can be seen that all the K-S Z-values were not significant at the 0.05 level ( $p>0.05$ ). This meant that the mean scores of attitude of taxpayer, quality of public governance and tax compliance cost were normally distributed. Following this conclusion with respect to normality of variable values, the study used parametric tool of statistics in subsequent analyses.

\section{Logistic Regression Analysis}

In this study, the logistic regression analysis was used for further tests. Logistic regression is a regression model suitable for modeling binary or dichotomous outcomes. In one model, the independent variables can be either categorical or continuous, or a mix of both. The significance of variables in predicting the concept of tax compliance either complies or does not comply (Hosmer \& Lemeshow, 2000). The results are presented in Table 8.

Table 8: Omnibus Tests

\begin{tabular}{lcc}
\hline & Chi-square & Significant \\
\hline Model & 12.647 & 0.005 \\
\hline
\end{tabular}

Omnibus Tests was used to indicate how well the model performs compared to the model without independent variables. The performance of the model was measured by observing the significance value. As shown in Table 8 the significance value was 0.005 which was less than level of 
significance (alpha) 0.05 . Thus, it shows that the model performed well compared to the model without the independent variables. In addition, the Cox and Snell R Square was used to see the total variations of tax compliance which can be explained by factors influencing tax compliance (Table 9). This comprised attitude of taxpayers, quality of public governance and tax compliance cost.

Table 9: Cox \& Snell R Square and Nagelkerke R Square

\begin{tabular}{lcc}
\hline & Cox \& Snell R Square & Nagelkerke R Square \\
\hline Model & 0.225 & 0.267 \\
\hline
\end{tabular}

As shown in Table 9, the value was 0.225 which indicated that 22.5 $\%$ of the total variations in tax compliance can be explained by factors influencing tax compliance. This comprises attitude of taxpayers, quality of public governance and tax compliance cost. Besides that, the value of the Nagelkerke R Square was 0.267 . This indicated that a moderate relationship existed between the tax compliance and factors influencing tax compliance. These comprised attitude of taxpayers, quality of public governance and tax compliance cost.

Table 10: Hosmer and Lemeshow Test

\begin{tabular}{lcc} 
& Chi-square & Significant \\
\hline Model & 10.191 & 0.252 \\
\hline
\end{tabular}

The Hosmer-Lemeshow test was used to test the goodnesss-of-fit. Based on Table 10, the chi-square value for the Hosmer-Lemeshow Test was 10.191 with a significance level of 0.252 . Since the significance value (0.252) was more than $(0.10)$, we can conclude that the model was a good fit for the data.

Table 11: Variables in the Equation

\begin{tabular}{lcccc}
\hline \multicolumn{1}{c}{ Variables } & B & Significance & Exp(B) & Interpretation \\
\hline Constants & 2.491 & 0.045 & 12.076 & Significant \\
Attitude of taxpayer & -0.722 & 0.160 & 0.486 & Not significant \\
Quality of Public Governance & -0.547 & 0.027 & 0.579 & Significant \\
Tax compliance cost & -0.003 & 0.991 & 0.997 & Not significant \\
\hline
\end{tabular}

The Wald p-value statistics was used to determine the significant variables in explaining the dependent variable. As shown in Table 11, only 
quality of public governance was significant since the value was less than 0.1 . Attitude of taxpayer and tax compliance cost was not significant since the value of the variables were more than 0.1 . It can be concluded that only quality of public governance was significant in explaining the dependent variable. The findings showed the influence of tax compliance and the three factors namely attitude of taxpayers, quality of public governance and tax compliance cost. Based on a regression analysis, the results (Table 12) showed only hypothesis $\mathrm{H} 2$ influenced tax compliance among health practitioners. Hypotheses $\mathrm{H} 1$ and $\mathrm{H} 3$ did not influence tax compliance among health practitioners.

Table 12: Overall Results of the Study

\begin{tabular}{|c|c|c|}
\hline Hypotheses & Description & Result \\
\hline $\mathrm{H} 1$ & $\begin{array}{l}\text { There is a significant relationship between attitude } \\
\text { of taxpayers and income tax compliance among } \\
\text { private health practitioners }\end{array}$ & Not supported \\
\hline $\mathrm{H} 2$ & $\begin{array}{l}\text { There is a significant relationship between quality } \\
\text { of public governance and income tax compliance } \\
\text { among private health practitioners. }\end{array}$ & Supported \\
\hline $\mathrm{H} 3$ & $\begin{array}{l}\text { There is a significant relationship between tax } \\
\text { compliance cost and income tax compliance among } \\
\text { private health practitioners }\end{array}$ & Not supported \\
\hline
\end{tabular}

The first objective was to examine the relationship between attitude of taxpayers and tax compliance among private health practitioners. According to Young et al. (2016), attitudes of taxpayers represented the positive and negative evaluations that an individual holds. It was assumed that attitudes encouraged individuals to act accordingly. H1 suggested that there is a relationship between attitude of taxpayer and tax compliance among private health practitioners. The result obtained in this study did not show a significant relationship between attitude of taxpayer and tax compliance among health practitioners. Thus, this implies that the attitude of a taxpayer would not impact tax compliance among private health practitioners.

The second objective was to examine the relationship between quality of public governance and tax compliance among private health practitioners. $\mathrm{H} 2$ suggested that there was a significant relationship between quality of public governance and tax compliance among private health practitioners. Findings in this study showed a significant relationship between quality of public governance and tax compliance among private health practitioners. 
Therefore, it suggested that quality of governance plays an important role in achieving good governance towards an efficient tax system which is consistent with Machogu (2015).

The third objective was to examine the relationship between cost of tax compliance and tax compliance among private health practitioners. Analysis of results showed that $\mathrm{H} 3$ was not supported. This indicated that compliance cost did not significantly influence tax compliance among private health practitioners. This finding contradicts Bruno (2019) which suggested that compliance cost influenced tax compliance.

\section{CONCLUSIONS}

Taxation plays a key role in achieving SDGs by reducing disparities within and across societies, supporting stronger and more accountable political institutions, as well as driving the economy towards a more sustainable direction. The limited number of studies regarding the factors influencing tax compliance among private health practitioners in Malaysia was one of the main reasons for this study to be conducted, despite many similar studies which have been conducted in other countries. Health practitioners who owned clinics were chosen as the sample of the study due to the problem highlighted by IRBM. Three hypotheses were developed in order to examine the relationship between attitude of taxpayers, quality of public governance, and cost of tax compliance and tax compliance among private health practitioners in Malaysia. The results of the study showed that only quality of public governance had significant relationship with tax compliance among health practitioners while attitude of taxpayer and cost of tax compliance did not significantly influence tax compliance among private health practitioners.

This study contributes to knowledge particularly in providing current evidence of tax compliance among health practitioners. Additionally, the findings highlight the importance of educating health practitioners on tax compliance. As such, this study can also provide guidance to regulators in planning for more effective tax education and awareness programs. Nevertheless, this study has some limitations. Firstly, the response rate was low due to lack of cooperation from the respondents. However, we had taken 
the necessary measures to increase the number of responses. This was done by personally distributing the questionnaires by hand and through emails. Secondly, since this study used questionnaires as the research instrument, the result might not reflect the real factors that influence tax compliance among private health practitioners. Therefore, it is recommended that future studies conduct qualitative interviews to gain in-depth insights on factors influencing tax compliance.

\section{ACKNOWLEDGEMENT}

The authors would like to acknowledge the assistance from the Ministry of Higher Education for HICoE research funding, Accounting Research Institute, Universiti Teknologi MARA, Malaysia for all supports and resources.

\section{REFERENCES}

Beck, M. L., Bryman, A., \& Liao, T. F. (2004). The SAGE encyclopedia of social science research methods. https://doi.org/10.4135/9781412950589

Bruno, R. L. (2019). Tax enforcement, tax compliance and tax morale in transition economies: A theoretical model. European Journal of Political Economy, 56, 193-211.

Bulutoding, L., \& Habbe, A. H. (2018). The influence of akhlaq to tax compliance behavior, and Niyyah as mediating variable of Moslem taxpayers in Malaysia. Scientific Research Journal (SCIRJ), VI(I), 1-9.

Chyz, J. A., Gaertner, F., Kausar, A., \& Watson, L. (2014, January). Overconfidence and aggressive corporate tax policy. In Proceedings. Annual Conference on Taxation and Minutes of the Annual Meeting of the National Tax Association (Vol. 107, pp. 1-47). National Tax Association.

Dwita, S., Cheisviyanny, C., Helmy, H., Honesty, H. N., Handayani, D. F., \& Helmayunita, N. (2020, March). A Portrait of Medical Doctors' 
Tax Knowledge in Padang. In $4^{\text {th }}$ Padang International Conference on Education, Economics, Business and Accounting (PICEEBA-2 2019) (pp. 129-133). Atlantis Press.

Fan, S., Pang, Y., \& Pestieau, P. (2020). A model of the optimal allocation of government expenditures. Journal of Public Economic Theory, 22(4), 845-876.

Fatt, C. K.\& Ling, L. M. (2008). Tax practitioners perception on tax audit and tax evasion: Survey evidence in Malaysia. Proceedings of the Eighth International Business Research Conference, Dubai, World Business Institute.

FMT News. (2017). We are not tax cheats, says private medical specialist's body. Retrieved from https://www.freemalaysiatoday.com/category/ nation/2017/09/

Fochmann, M., \& Kroll, E. B. (2016). The effects of rewards on tax compliance decisions. Journal of Economic Psychology, 52, 38-55.

Gobena, L. B., \& Van Dijke, M. (2016). Power, justice, and trust: A moderated mediation analysis of tax compliance among Ethiopian business owners. Journal of Economic Psychology, 52, 24-37.

Hearson, M. (2019). Fair tax for development. Retrieved from https://www. sustainablegoals.org.uk/fair-tax-for-development/

Hosmer, D. W., \& Lemeshow, S. (2013). Applied logistic regression. New York: Wiley.

IRBM. (2016). Annual Report 2016: Inland Revenue Board of Malaysia.

IRBM. (2017). Annual Report 2017: Inland Revenue Board of Malaysia.

Jaffar Harun, R., \& Abu Bakar, M. J., \& Mohd Tahir, I. (2011). Ethics on tax evasion. International Business and Management, 2(1), 122-128.

Jayawardane, T. G. S, D., \& Low, K. (2017). Exploring key determinants 
of tax compliance decision among individual taxpayers in Sri Lanka. European Journal of Business and Management, 9(3), 125-35.

Kasipillai, J., Baldry, J., \& Rao, D. P. (2000). Estimating the size and determinants of hidden income and tax evasion in Malaysia. Asian Review of Accounting, 8(2), 25-42.

Ketema D. W. (2016). Factors affecting tax compliance of small and medium business profit taxpayers in Addis Ababa (Doctoral dissertation, Addis Ababa University).

Kogler, C., Mittone, L., \& Kirchler, E. (2016). Delayed feedback on tax audits affects compliance and fairness perceptions. Journal of Economic Behavior and Organization, 124, 81-87.

Long, C., \& Miller, M. (2017). Taxation and the sustainable development goals. do good things come to those who tax more? Retrieved from https://www.globaltaxjustice.org/sites/default/files/11536.pdf

Machogu, P. B. (2015). Factors Influencing an individual's income tax compliance: A case of selected MSES in Kasarani constituency (Doctoral dissertation, University of Nairobi).

Mafrolla, E., \& D'Amico, E. (2016). Tax aggressiveness in family firms and the non-linear entrenchment effect. Journal of Family Business Strategy, 7(3), 178-184.

Mas'ud, A., Aliyu, A. A., Gambo, E. J., Al-Qudah, A. A., \& Al Sharari, N. (2014). Tax rate and tax compliance in Africa. European Journal of Accounting Auditing and Finance Research, 2(3), 22-30.

Mehari, D., \& Pasha, S. A. (2017). Factors affecting voluntary compliance of category 'C' taxpayers' attitude of Arbaminch, SNNPR, Ethiopia. International Journal of Scientific and Research Publications, 7(6), 48-63.

Mohdali, R., Isa, K., \& Yusoff, S. H. (2014). The impact of threat of punishment on tax compliance and non-compliance attitudes in Malaysia. Procedia - Social and Behavioral Sciences, 164(8), 291-297. 
OECD (2018). Accessed from https://www.oecd.org/tax/countries-muststrengthen-tax-systems-to-meet-sustainable-development-goals.htm

Palil, M. R. (2010). Tax knowledge and tax compliance determinants in self-assessment system in Malaysia (Doctoral dissertation, University of Birmingham).

Reshetov, K. Y., Mysachenko, V. I., \& Mikhailova, A. S. (2020). A comparative analysis of tax systems in Russia and Germany. In Complex Systems: Innovation and Sustainability in the Digital Age. 169-175. Springer, Cham.

Saad, N. (2014). Tax knowledge, tax complexity and tax compliance: Taxpayers view. Procedia - Social and Behavioral Sciences, 109(1), 1069-1075.

Saad, R. A. J., Wahab, M. S. A., \& Samsudin, M. A. M. (2016). Factors influencing business Zakah compliance behavior among moslem businessmen in Malaysia: A research model. Procedia - Social and Behavioral Sciences, 219, 654-659.

Sekaran, U., \& Bougie, R. (2016). Research methods for business: A skill building approach. John Wiley \& Sons.

Stefura, G. (2011). The role played by economic and noneconomic variables in the analysis of tax compliance. Review of Economics and Business Studies, 4(2), 105-120.

Tsaurai, K. (2020). Tax revenue and financial development in emerging markets. Academy of Accounting and Financial Studies Journal, 24(5), $1-10$.

Young, A., Lei, L., Wong, B., \& Kwok, B. (2016). Individual tax compliance in China: A review. International Journal of Law and Management, $58(5), 1-12$. 